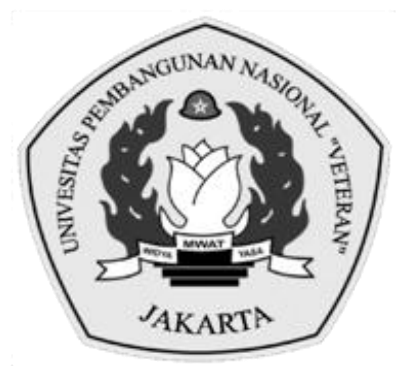

\title{
DOES DIVULGATION OF CORPORATE SOCIAL RESPONSIBILITY INFORMATION INFLUENCE EARNINGS RESPONSE COEFFICIENT?
}

\author{
Nadhira Hardiana* \\ nadhirahardiana@ecampus.ut.ac.id \\ Universitas Terbuka, Indonesia \\ *corresponding author
}

\begin{abstract}
Companies that have reported on their social responsibility activities certainly expect an increase in the Firm value. The profits generated by the company have the power of response. The market response to earnings information can be seen from the size of the Earnings Response Coefficient (ERC). This research aims to examine if the divulgation of Corporate Social Responsibility (CSR) information influenced the ERC. CSR disclosure is measured using a dichotomous method, while ERC is obtained from the regression between Cumulative Abnormal Return (CAR) and Unexpected Earning (UE). The findings of this research show that the divulgation information of CSR in the sustainability reports has no effect on the ERC.
\end{abstract}

Keywords: CSR; ERC; Cumulative Abnormal Return; Unexpected Earnings

\begin{abstract}
Abstrak
Perusahaan yang telah melaporkan kegiatan tanggung jawab sosialnya tentu mengharapkan peningkatan nilai Perusahaan. Keuntungan yang dihasilkan oleh perusahaan memiliki kekuatan respon. Respon pasar terhadap informasi laba dapat dilihat dari besar kecilnya Earnings Response Coefficient (ERC). Tujuan dari penelitian ini adalah untuk menguji apakah penyebaran informasi Corporate Social Responsibility (CSR) mempengaruhi ERC. Pengungkapan CSR diukur dengan menggunakan metode dikotomis, sedangkan ERC diperoleh dari regresi antara Cumulative Abnormal Return (CAR) dan Unexpected Earning (UE). Temuan penelitian ini menunjukkan bahwa pengungkapan informasi CSR dalam laporan keberlanjutan tidak berpengaruh terhadap ERC.
\end{abstract}

Kata Kunci: CSR; ERC; Cumulative Abnormal Return; Unexpected Earnings

\section{INTRODUCTION}

The purpose of the business, in general, is not just to maximize profit. Another objective is to benefit the business's owner, ensure its continuation (a going concern), and benefit the surrounding community (Martono and Harjito, 2010). Businesses should conserve natural resources rather than exploit them to create enough to meet the demands of the community to secure the continuity of their business and the success of the surrounding community. If the corporation 
Abuses the environment, there will undoubtedly be severe protests from environmental activists, preventing the company from achieving the going concern aim and prospering the community, as this activity may jeopardize people's livelihoods.

Article 74 paragraph (1) of Law No. 40 of 2007 concerning Limited Liability Companies requires businesses to exercise social responsibility, often referred to as Corporate Social Responsibility (CSR). The article expresses that companies that do business in natural resources are obligated to make responsible choices, balancing social and environmental concerns with financial benefit. The government requires businesses to fulfill social and environmental responsibilities to achieve sustainable economic growth and enhance the quality of life in the community and the environment, which is expected to benefit the firm, the community in the local area, and society in general in the future. (Government of the Republic of Indonesia, 2007).

To find out about the company's social responsibility, investors need a reporting tool that can report environmental, social, and financial aspects, known as sustainability reporting. Verecchia in Rusdin (2016) states that companies will divulge the information from an economic perspective if it increases its value. Thus, companies that have reported on their social responsibility activities certainly expect an increase in the firm value.

Firm value is significant not only for the company but also for investors in making investment decisions because it reflects how the performance of a company so can affect investors' perceptions of a company. Investors will become increasingly confident that they will benefit from companies with high corporate values. Apart from the sustainability report, the main source of information utilized to make decisions is profit, as shown in the business's financial statements. Syafrudin in Wulandari \& Wirajaya (2014) says that investors respond differently to accounting earnings information according to the credibility or quality. Thus, it can be said that the profits generated by the company could respond to the market. Earnings Response Coefficient (ERC) size provides insight into how the market reacts to earnings information.

Rusdin (2016) researched the effect of CSR disclosure on ERC. His empirical research indicates that CSR disclosure has a detrimental effect on ERC. Another study conducted by Palupi et al. (2017) showed different results. Their research findings state that the publication of CSR information has no significant impact on ERC. Another study conducted by Dazia et al. (2019) also gave different results. Their research shows that CSR disclosure affects the Accounting Profit Response Coefficient.

Due to the inconsistency in the results of previous studies, this research aims to examine if the divulgation of CSR Information influenced the ERC. The findings of this study are likely to contribute to a greater understanding among regulators of the critical nature of legislation governing information disclosure and openness about CSR to promote green accounting. Additionally, in comparison to prior research, this study contributes to the renewal of the study sample time. 


\section{LITERATURE REVIEW}

\section{Corporate Social Responsibility}

Corporate Social Responsibility (CSR) does not have a universally agreedupon definition. Various authors develop different definitions of CSR based on their background, interests, and the frame of mind of the references they use. Additionally, businesses' implementation and explanation of CSR vary since the concept and components of CSR vary between nations and regions. However, in general, CSR refers to a company's responsibility to its stakeholders, particularly the communities in which it operates, to conduct a sustainable business.

CSR is defined by the World Company Council for Sustainable Development (2004) as a business commitment to contribute to sustainable economic development by taking the initiative to enhance employees, families, local communities, and society at large to improve their quality of life.

In 2001, the European Union Commission issued a Green Paper to promote the CSR framework in Europe. CSR is defined by the European Union Commission (EU, 2001) as a concept in which a company voluntarily incorporates social and environmental concerns into its business operations and interactions with stakeholders because it is increasingly aware that responsible behavior leads to long-term business success. Then in 2011, the European Union Commission (EU, 2011) issued "A renewed EU strategy 2011-2014 for CSR" suggested a new definition of CSR as "enterprises' responsibility for their impacts on society," which means that businesses must integrate social, environmental, ethical, human rights, and consumer care into their operations to fulfill their CSR as well as their core strategy of working closely with their stakeholders, with the aim of:

- It maximizes shared value for its owners (shareholders) and other stakeholders and society in general.

- Identify, prevent, and reduce adverse impacts that may occur.

The definition of CSR is stated in Law Number 40 of 2007 concerning Limited Liability Companies Article 1 point 3 as follows (Government of the Republic of Indonesia, 2007): Social and Environmental Responsibility is the Company's commitment to participate in sustainable economic development to improve the quality of life and a sustainable environment. Beneficial, both for the Company itself, the local community, and society in general.

ISO 26000 on International Guidance for Social Responsibility was issued before the close of 2010, specifically on November 1,2010 . The release of ISO 26000 has made the parties aware that social responsibility is not merely a corporate obligation but has become our responsibility, both private and public institutions. Individuals or entities, for-profit organizations, or self-proclaimed non-profits. Furthermore, ISO 26000 provides a clear definition of social responsibility (Mardikanto, 2014): Transparency and ethical conduct that promotes long-term growth, good health, and social well-being are key components of corporate social responsibility (CSR). As required by law and in line with international rules of conduct, the organization considers the expectations of its stakeholders and puts this into effect in its partnerships. 


\section{Earnings Response Coefficient}

Earnings Response Coefficient (ERC) is a reaction to a company's earnings announcements that indicates the quality of the earnings disclosed. The high and low ERC is determined mainly by the responsiveness obtained from the information contained in the company's profits.

Scott (2009) states that the market has expectations about published profits at the announcement of financial statements. If the actual profit is more than investor expectations, this will be good news. However, if the actual profit is less than investors' expectations, this will be bad news.

\section{The Effect of CSR Information Disclosure on ERC}

Ball and Brown in Maharani (2014) state that changes in stock prices move according to future earnings expectations. Investors' judgments will be influenced by the value of information given in the announcement of earnings data. Investing in a company is largely determined by how it announces its annual report to the public, which has a significant impact on investor behavior. It is intended that by disclosing the company's social responsibilities in its annual report, the community will see its activities and goods as having more value and legitimacy.

A wide range of correlations may be found between the amount and quality of information that organizations release and their performance in the market. Lang and Lundholm in Sayekti and Wondabio (2007) state that there is a positive relationship between disclosure and company market performance. The annual report is one of the media used by companies to communicate directly with investors. According to Healy et al. in Sayekti and Wondabio (2007), companies' disclosure of information in annual reports is expected to reduce information asymmetry and agency problems.

Various studies have tested the difference in ERC on earnings announcements based on the premise that the information content of earnings will be greater when the company's prospects are unclear. This shows that the ERC rises in direct proportion to the degree of apprehension investors have about the company's prospects. It is hoped that if the company discloses information in its annual report, it can reduce this uncertainty. Thus, the disclosure of information will reduce ERC. Based on this explanation, the hypotheses proposed in this study are:

\section{Ha: The level of CSR information disclosure in the annual report influences ERC.}

\section{RESEARCH METHODOLOGY}

The nature of this research is quantitative because the research data is in numbers, and the analysis uses statistics. The analytical method used in this research uses the ordinary least squares (OLS) regression model with SPSS 16 . The data for this study was derived from secondary sources, including annual financial reports and sustainability reports published on the Indonesian Stock Exchange (IDX) in 2018. 


\section{Sample and Population}

The data population for this study was comprised of firms that were publicly traded on the Indonesian Stock Exchange (IDX) in 2018. The sampling technique was carried out by purposive sampling method, which is based on specific criteria, namely a company that published a sustainability report in 2018 and must have complete daily share price data obtained from finance.yahoo.com. There are 32 companies as the relevant samples in this study.

\section{Operationalization of Variable}

ERC is a dependent variable in this study. ERC is a coefficient $(\beta)$ obtained from the regression between Cumulative Abnormal Return (CAR) and Unexpected Earning (UE). To calculate the ERC value in this study, Susanto's (2012) research. The first stage is to ascertain daily stock and market returns. The formula calculates daily stock return

$$
\begin{aligned}
& \text { Formula 1. Calculation of } C A R \\
& R_{i t}=\frac{P_{i t}-P_{i t-1}}{P_{i t-1}}
\end{aligned}
$$

$\mathrm{R}_{\mathrm{it}}$ indicates the return of company $\mathrm{i}$ on day $\mathrm{t}, P_{i t}$ is the closing price of stock i on day $\mathrm{t}$, and $P_{i t-1}$ is the closing price of stock i on day t-1.

Return daily market can be calculated as follows

$$
\begin{aligned}
& \text { Formula 2. Calculation of } R m_{t} \\
& R m_{t}=\frac{I H S G_{t}-I H S G_{t-1}}{I H S G_{t-1}}
\end{aligned}
$$

$\mathrm{Rm}_{\mathrm{t}}$ indicates the return of the daily market, $\mathrm{IHSG}_{\mathrm{t}}$ is the composite Stock Price Index on day $t$, and IHSG $_{t-1}$ is the composite Stock Price Index on day t-1.

The next stage is to calculate the abnormal return obtained from

Formula 3. Calculation of $A R_{i t}$

$$
A R_{i t}=R_{i t}-R_{m t}
$$

$\mathrm{AR}_{\mathrm{it}}$ indicates the abnormal returns of the company $\mathrm{i}$ in period $t, \mathrm{R}_{\mathrm{it}}$ is the company's return in period $t$, and $\mathrm{Rm}_{\mathrm{t}}$ is the market return in period $\mathrm{t}$.

Next, calculate the Cumulative Abnormal Return (CAR) variable using the formula

$$
\begin{aligned}
& \text { Formula 4. Calculation of } C A R_{i} \\
& C A R_{i(-3,+3)}=t_{t=\sum-3+3} A R_{i t} \ldots \ldots \ldots \ldots
\end{aligned}
$$

$\mathrm{CAR}_{\mathrm{i}(-3,+3)}$ indicates the cumulative abnormal return for the company $\mathrm{i}$ during the observation period is approximately three days from the publication date of the financial statements ( 3 days before, one day of the publication date, and three days after the publication date of the financial statements) and $A R_{i t}$ is the abnormal return for the company i on day t.

Unexpected Earning (UE) for each company is calculated using a random walk model. EU is the difference between the accounting profit expected by the market. UE is measured according to Susanto's (2012) research

$$
\begin{aligned}
& \text { Formula 5. Calculation of } U E_{i t} \\
& \qquad U E_{i t}=\frac{E P S_{i t}-E P S_{i t-1}}{P_{i t-1}} \ldots \ldots \ldots \ldots . . . . . . . .
\end{aligned}
$$

$U E_{i t}$ indicates the unexpected earnings of the company $\mathrm{i}$ in period $\mathrm{t}, E P S_{i t}$ is the earnings per share of the company $\mathrm{i}$ in period $\mathrm{t}, E P S_{i t-1}$ is the earnings per share of the company i in period $\mathrm{t}-1$, and $P_{i t-1}$ is the market return on the share 
price of the company $\mathrm{i}$ in period $\mathrm{t}-1$.

After the CAR and UE values are obtained through these calculations, the linear regression model is used to determine ERC can be formulated as follows

Formula 6. Calculation of $C A R_{i t}$

$$
C A R_{i t}=\beta_{0}+\beta_{1} U E_{i t}+e
$$

Information:

CARit = Cumulative abnormal returns of each company throughout the observation period

UEit = Unexpected earnings company $\mathrm{i}$ on the earnings announcement

$0=$ Constant

$1=$ ERC

e $\quad=$ The error component in the model for the firm $\mathrm{i}$

CSR is an independent variable in this study. This CSR disclosure measure covers three main categories: economic, environmental, and social, using the reporting principles and standard disclosures issued by the Global Reporting Initiative (GRI). According to Sayekti and Wondabio (2007), the calculation of CSR disclosure in this study uses a dichotomous approach. If a CSR item is disclosed, it is assigned a value of 1 . Otherwise, it is assigned a value of 0 . The scores for each item are then added together to get the total score for each firm, which is calculated using the formula

$$
\begin{aligned}
& \text { Formula 7. Calculation of CSRI } \\
& \qquad C S R I_{j}=\frac{\sum x_{i j}}{n_{j}} \ldots \ldots \ldots \ldots \ldots \ldots \ldots \ldots \ldots \ldots \ldots \ldots \ldots
\end{aligned}
$$

CSRIj indicates the disclosure of social responsibility ratio in business $j, n j$ is the total number of items disclosed in annual report company $\mathrm{j}$, and Xij is a dummy variable (1 if disclosed, otherwise 0 ).

\section{Research Model}

The ordinary least squares (OLS) regression model is being used in this study to determine if the disclosure of CSR information affects the ERC. The formulation of the model is as follows

$$
\begin{aligned}
& \text { Formula 8. Research Analysis Model } \\
& Y_{i t}=\beta_{0}+\beta_{1} X_{1}+\beta_{2} X_{2}+\beta_{3} X_{1} * X_{2}+e
\end{aligned}
$$

Description:

$\mathrm{Y}_{\text {it }} \quad=$ Cumulative Abnormal Return (CAR)

$\mathrm{X}_{1} \quad=$ Unexpected Earning

$\mathrm{X}_{2}=$ Corporate Social Disclosure Index

$\beta_{0} \quad=$ Constant

$\beta_{\mathrm{i}} \quad=$ The coefficient of each variable $(\mathrm{i}=1,2)$

$\mathrm{e} \quad=$ error term

\section{RESULT AND DISCUSSIONS}

\section{Normality Test}

The normality test aims to determine if the data in the regression model, namely the residual variable, has a normal distribution. The Kolmogorov-Smirnov 
normal test may evaluate whether the data is normally distributed or not. The results of the normality calculation using SPSS are shown in Table 1.

Table 1. Kolmogorov-Smirnov. Normality Test

\begin{tabular}{lc}
\hline & $\begin{array}{c}\text { Unstandardized } \\
\text { Residual }\end{array}$ \\
\hline Kolmogorov-Smirnov Z & 1.096 \\
Asymp. Sig. (2-tailed) & 0.180 \\
\hline
\end{tabular}

Source: Research Data (2019)

Table 1 shows the Asymp values. Sig. (2-tailed) 0.180 is more than 0.05, meaning it accepts $\mathrm{HO}$ and rejects $\mathrm{Ha}$. So, we can conclude that the data used in this study is normally distributed. In other words, this research data can represent the population.

\section{Multicollinearity Test}

The multicollinearity test establishes whether the independent variables are correlated (strong relationships). One of the most accurate ways to detect the presence or absence of this multicollinearity symptom is to use the Tolerance and VIF (Variance Inflation Factor) methods. If the Tolerance value is greater than 0.10 , no multicollinearity exists, as well as the VIF value, there is no multicollinearity if the VIF value is less than 10 .

Table 2. Multicollinearity Test

\begin{tabular}{|c|c|c|c|c|c|c|c|c|}
\hline & \multirow{2}{*}{ Model } & \multicolumn{2}{|c|}{$\begin{array}{l}\text { Unstandardized } \\
\text { Coefficients }\end{array}$} & \multirow{2}{*}{$\begin{array}{c}\begin{array}{c}\text { Standardized } \\
\text { Coefficients }\end{array} \\
\text { Beta }\end{array}$} & \multirow{2}{*}{$\mathrm{t}$} & \multirow{2}{*}{ Sig. } & \multicolumn{2}{|c|}{$\begin{array}{l}\text { Collinearity } \\
\text { Statistics }\end{array}$} \\
\hline & & B & $\begin{array}{l}\text { Std. } \\
\text { Error }\end{array}$ & & & & Tolerance & VIF \\
\hline \multirow[t]{3}{*}{1} & (Constant) & -0.340 & 0.147 & & -2.308 & 0.028 & & \\
\hline & UE & -0.541 & 0.635 & -0.154 & -0.852 & 0.401 & 0.977 & 1.024 \\
\hline & CSRI & 0.617 & 0.460 & 0.243 & 1.341 & 0.190 & 0.977 & 1.024 \\
\hline
\end{tabular}

Source: Research Data (2019)

Table 2 shows that the tolerance value is 0.977 , which is more than 0.10 , and the VIF value is 1.024 , which is less than 10. As a result, it is possible to conclude that the independent variables (CSRI and UE) are unrelated (not multicollinearity occurs).

\section{Heteroscedasticity Test}

The heteroscedasticity test tests whether there is an inequality of variance between the residuals of one observation to another observation in the regression model. The following is the data from the heteroscedasticity test using the glejser test. 
Table 3. Heteroscedasticity Test

\begin{tabular}{llccccc}
\hline \multirow{2}{*}{ Model } & \multicolumn{2}{c}{$\begin{array}{c}\text { Unstandardized } \\
\text { Coefficients }\end{array}$} & \multicolumn{2}{c}{$\begin{array}{c}\text { Standardized } \\
\text { Coefficients }\end{array}$} & $\mathrm{t}$ & Sig. \\
& $\mathrm{B}$ & Std. Error & Beta & & \\
\hline 1 & (Constant) & -0.415 & 0.154 & & -2.690 & 0.012 \\
& UE & 6.186 & 4.817 & 1.763 & 1.284 & 0.210 \\
& CSRI & 0.965 & 0.516 & 0.380 & 1.871 & 0.072 \\
& UExCSRI & -20.759 & 14.739 & -1.958 & -1.408 & 0.170 \\
\hline
\end{tabular}

Source: Research Data (2019)

Based on the calculations from the output of the glejser test in table 3 above, it shows that no heteroscedasticity disorder occurs in the estimation process of the presupposition model parameters, where the significance value of the UE variable is 0.210 , the CSRI variable is 0.072 . The interaction value of UE and CSRI is 0.172 , which is a value greater than 0.05 . As a result, it is possible to conclude that heteroscedasticity does not exist.

\section{Autocorrelation Test}

The autocorrelation test analyzes if there is a link between the confounding error in period $t$ and the error in the prior $t 1$ period in the linear regression model using the Durbin Watson formula.

If the Durbin Watson value is smaller than $\mathrm{dl}$ or the Durbin Watson value is greater than the 4-dl value. There is autocorrelation, whereas the Durbin Watson value is between the du value and the 4 -du value. There is no autocorrelation, and if the Durbin Watson value is between the values of $\mathrm{dl}$ and du or the value of Durbin Watson is between the values of 4-du and 4-dl, it cannot be concluded.

Table 4. Autocorrelation Test

\begin{tabular}{cccccc}
\hline Model & $\mathrm{R}$ & R Square & $\begin{array}{c}\text { Adjusted R } \\
\text { Square }\end{array}$ & $\begin{array}{c}\text { Std. Error of the } \\
\text { Estimate }\end{array}$ & Durbin-Watson \\
\hline 1 & $0.364^{\mathrm{a}}$ & 0.133 & 0.040 & 0.331 & 2.039 \\
\hline
\end{tabular}

Source: Research Data (2019)

It can be observed in Table 4 that the value of Durbin Watson is 2.039 , while the values of $\mathrm{dl}, \mathrm{du}, 4-\mathrm{dl}$, and 4-du with a total of $\mathrm{k}=3$, and $\mathrm{n}=32$ are 1.2437, 1.6505, 2 , respectively 0.7563 , and 2.3495. Due to du (1.5736) < Durbin Watson $(2.039)<$ 4-du (2.3495), it is possible to infer that this linear regression model has no autocorrelation symptoms.

\section{Hypothesis Testing}

The $\mathrm{F}$ test is used to assess if the independent variable (X) has a simultaneous (together) influence on the dependent variable (Y). 
Hardiana, Does Divulgation of Corporate Social Responsibility...

Table 5. F-Test

\begin{tabular}{llccccc}
\hline \multicolumn{1}{c}{ Model } & $\begin{array}{c}\text { Sum of } \\
\text { Squares }\end{array}$ & df & $\begin{array}{c}\text { Mean } \\
\text { Square }\end{array}$ & F & Sig. \\
\hline \multirow{2}{*}{$\begin{array}{l}\text { Regression } \\
1\end{array}$} & 0.468 & 3 & 0.156 & 1.429 & 0.255 \\
Residual & 3.059 & 28 & 0.109 & & \\
Total & 3.528 & 31 & & & \\
\hline
\end{tabular}

Source: Research Data (2019)

As shown in Table 5, the significant value is more than 0.05 , namely 0.255 , or the computed $F$ value is 1.429 , which is less than the $F$ table value $(3 ; 27)=2.96$, indicating that CSR did not have a significant effect on ERC.

The impact of the independent variable on the dependent variable is determined using a partial t-test. The independent variable $(\mathrm{x})$ influences the dependent variable $(y)$ if the significance value is less than 0.05 .

Table 6. T-Test

\begin{tabular}{llccccc}
\hline & \multicolumn{2}{c}{ Unstandardized } \\
& \multicolumn{2}{c}{ Coefficients } & \multicolumn{2}{c}{$\begin{array}{c}\text { Standardized } \\
\text { Coefficients }\end{array}$} & & \\
\cline { 2 - 5 } Model & $\mathrm{B}$ & Std. Error & Beta & $\mathrm{t}$ & Sig. \\
\hline 1 & (Constant) & -0.415 & 0.154 & & -2.690 & 0.012 \\
& UE & 6.186 & 4.817 & 1.763 & 1.284 & 0.210 \\
& CSRI & 0.965 & 0.516 & 0.380 & 1.871 & 0.072 \\
& UExCSRI & -20.759 & 14.739 & -1.958 & -1.408 & 0.170 \\
\hline
\end{tabular}

a.Dependent variable: CAR

Source: Research Data (2019)

As seen in Table 6, the UE has a significant value of 0.210 , CSRI is 0.072 , and UExCSRI is 0.170 . These values are greater than 0.05 , so it can be concluded that Ha is rejected means CSR did not have a significant effect on ERC.

According to the above-mentioned test findings, the hypothesis proposed in this study which states that the level of CSR information disclosure in the annual report influences ERC, cannot be proven, or the hypothesis (Ha) is rejected. This hypothesis supports the results of previous empirical study conducted by Palupi et al. (2017), concluding that CSR information disclosure does not have a significant effect on ERC.

It shows the possibility that investors still provide a greater response to earnings information than social responsibility reports in making investment decisions. There is no significant effect between corporate social responsibility (CSR) and earnings response coefficient (ERC). 


\section{CONCLUSION}

This research examines if the divulgation of CSR Information influenced the ERC of firms that were publicly traded on the IDX during the year 2018. The results of the hypothesis test state that there is no influence between the divulgation of CSR Information in the company's sustainability report on the ERC. These results support previous empirical study conducted by Palupi et al. (2017), who concluded that the publication of CSR report has no significant impact on ERC. On the other hand, much earlier research has come to different conclusions. This is due to variations in the variables that affect the ERC.

The study's findings prove that the disclosure of CSR information does not affect ERC. It can be concluded that investors in making decisions still strongly refer to the amount of profit because investors estimate the company's prospects in the future by basing on the profits it earns from year to year. They are not paying too much attention to whether the company has carried out CSR activities because CSR provides more long-term benefits than short-term so that investors do not notice CSR information.

This study has limitations. Namely, the period used in this study is one year. This period is still concise, so the study results cannot be generalized. Therefore, it is recommended that further research consider a relatively more extended period so that the study results can be generalized.

\section{REFERENCES}

Cannon, Joseph P., William D. Perreault, Jr., E. Jerome McCarthy. 2009. Pemasaran Dasar: Pendekatan Manajerial Global. Sixteenth Edition. Jakarta: Salemba Empat.

Dazia, Ely., Maulita, Dian., \& Framita, Dien S. 2019. Analisis Pengungkapan Corporate Social Responsibility (CSR) dalam Laporan Tahunan Terhadap Koefisien Respon Laba Akuntansi. Jurnal Akuntansi Universitas Serang Raya.Vol 1, No 1, pp. 40-48.

EU. 2001. Green paper on promoting a European framework for Corporate Social Responsibility. European Union, Brussels.

EU. 2011. A renewed EU strategy 2011-2014 for Corporate Social Responsibility.COM 681 final. European Union, Brussels.

Gujarati, Damodar \& Porter, Dawn. 2008. Basic Econometrics. McGraw-Hill/Irwin: 5 edition.

Harazin, Piroska \& Kósi, Kálmán. 2013. Social Challenges: Social Innovation through Social Responsibility. Periodica Polytechnica: Social and Management Sciences, pp. 27-38.

Mardikanto, Totok. 2014. CSR (Corporate Social Responsibility): tanggung jawab sosial korporasi. Bandung: Alfabeta.

Martono \& Harjito, D. Agus. 2010. Manajemen Keuangan (Edisi 3). Yogyakarta: Ekonisia.

Pemerintah Republik Indonesia. 2007. Undang-undang Nomor 40 Tahun 2007 tentang Perseroan Terbatas. Jakarta.

Palupi, Wulandari \& Safitri. 2017. Pengaruh Pengungkapan Informasi Proyeksi dan 
Tanggung Jawab Sosial Perusahaan terhadap Koefisien Respon Laba. Jurnal Riset Akuntansi dan Keuangan Indonesia, 2(1), pp. 91-101

Porter, M. E., \& Kramer, Mark R. 2006. Strategy and society: the link between competitive advantage and Corporate Social Responsibility. Harvard Business Review 84, no. 12.

Rusdin. 2016. Pengungkapan Corporate Social Responsibility (CSR) dan Implikasinya terhadap Earning Response Coefficient (ERC). Jurnal AdBispreneur Vol. 1, No. 2, pp. 153-164.

Sayekti, Yosefa \& Wondabio, L.S. 2007. Pengaruh CSR Disclosure terhadap Earning Response Coefficient. Simposium Nasional Akuntansi X Unhas Makassar, pp. 13.

Scott, W. R. 2009. Financial Accounting Theory. Fifth Edition. Canada: Prentice-H.

Social Service Europe. 2012. Social innovation: the role of social service providers. Briefing paper. social innovation the role of social service providers.pdf

Susanto, Yulius Kurnia. 2012. Determinan Koefisien Respon Laba. Jurnal Akuntansi dan Manajemen, Vol.23, No.3, pp. 158.

World Business Council for Sustainable Development (WBCSD). 2004. Crosscutting themes-Corporate responsibility. http://www.wbcsd.org/ 
EQUITY, Vol. 24, No.1, 2021, 211-222

This page is intentionally left blank

for fulfillment purposes 